\title{
Factors Determining Female Labor Participation in Job Market in the Middle East and North Africa (MENA) Countries
}

\author{
Anas Abdulrahman Almiman ${ }^{1}$, Aris Chandra Pradikta ${ }^{1}$, and Raeef Altamimi ${ }^{2}$ \\ ${ }^{1}$ Graduate School of International Relations, Ritsumeikan University, Kyoto, Japan, ${ }^{2}$ Graduate \\ School of Inter-Religious Studies, Universitas Gadjah Mada, Yogyakarta, Indonesia
}

Correspondence: Aris Chandra Pradikta (email: chandraaris@gmail.com)

\begin{abstract}
Women's engagement in the broader social life is part of policy objectives in today's world that most governments aim to achieve. Likewise, the issue is crucial in most Muslim majority countries, especially in the Middle East and North Africa (MENA). As the regions have characteristics of a smaller number of women's participation in the formal labor market than many other countries, this study investigated the factors that determine women's participation by measuring data of governance, industrial transformations, and education from 1980 to 2014. This study used robust panel data methods to calculate the interdependencies of those variables. Based on the estimation, prominent factors that have positive correlations with the participation are good governance and the transitions from agriculture to industrial and service economy. Meanwhile, financial literacy and education have limited impacts on participation.
\end{abstract}

Keywords: labor economics; women's participation; MENA countries; job market

\section{Introduction}

Women's participation in the job market is a global agenda for promoting gender equality and empowerment. These efforts have also been an ongoing target in Sustainable Development Goals (SDGs). In general, women's choices to stay at home or to participate in the formal labor market are based on several factors. These encompass levels of economic development, structural change of economy from agrarian to service-oriented and industry, and institutional structures of a country (Gauthier et al., 2016; Jensen, 2017).

Meanwhile, factors that determine women's participation in the labor market within Muslim majority countries in MENA regions are arguably different from other countries (Moghadam, 1991). Despite the fact that secular-liberal values are part of most Middle East and North African countries' constitutions, nevertheless, researchers argued that females' role in the job market and women's development are impeded by other structural factors. Previous studies hint out the social institutions, such as religion, and other social values (AlMunajjed, 2010), as determinants of female labor force participation. Even though female participation in broader scope has experienced an increase in many areas, there remains a limited trend for women's participation in the formal labor 
market. Accordingly, the existing condition is also known as the MENA paradox.

The existence of the MENA paradox is shown by educational attainment that does not positively correlate with female labor participation in general (Assaad et al., 2018). These issues, in turn, undermine the achievement of women's involvement as part of Sustainable Development Goals (SDGs) within those countries. Furthermore, since mass protests, industrial reformations, and rural-urban migrations have been taking place in most Muslim majority countries in the MENA region, these circumstances also enable us to re-examine the engagement of female labor participation in the job markets.

The participation of women is both driving forces and a sign of ongoing outcomes for the economic development in that area. However, the limitation of evidence that attempts to examine the highlighted social and political conditions in the MENA region leaves a gap for researchers to address the issues. In this study, the authors attempted to pay attention to the social and political dynamics, such as mass protests, industrial reformations, and rural-urban migrations, by testing the relevant variables. In turn, the authors included indicators that encompass educational attainment, cost of living, capital stock, government compensation, degree of industrialization, and quality of governance. The tested data of educational attainment and other indicators enable us to understand the limitation of the conventional theory of women participation and compare it with broader structural forces in this study.

Data in this research was obtained from World Bank and Penn World Table from 19802014. In short, the authors used a dynamic model to analyze the data. Nevertheless, even though both sources provide adequate input for the analysis in this study, there are also a handful of limitations. Firstly, the authors acknowledged the shortcomings of this study due to the missing information in several countries, such as Yemen, Egypt, and Syria, as a result of the economic and political dynamics since 2012.

Secondly, the limitation of testing the recent data is due to the imbalance of information from the available sources. On the one hand, the annual data from the World Bank has been published until 2019. On the other hand, some references from the Penn World Table are yet available. These circumstances, in turn, can undermine the result of the statistical outputs when the authorsforge to employ the recent data. Therefore, the authors also suggest other researchers for using different methods to complement this study.

\section{Research Methods}

\section{Data and Sources}

Annual time series data of MENA countries from 1980 to 2014 have been used. Mainly the data has been gathered from the World Development Indicator (WDI) data set and World Penn Table. The variables of interest include the female labor participation rate. The rate of labor force participation for ages 15-24 is the population proportion that is economically active. In other words, all people who supply labor to produce goods and services during a specified period. This study employed data on education, which are years of schooling and returns to education; see Human capital in Penn World Tables 9. Another core independent variable is taken as the cost of living indicates price level of household consumption, the price level of USA GDP in 2011=1 from Penn World Tables 9. 
This study considers capital stock at current PPPs (in a million 2011US\$) as it is functionally related to labor force participation. Labor compensation is a core endogenous variable in the labor demand and labor supply function. Thus this study considers the share of labor compensation in GDP at current national prices as a proxy of wage. Since many financial development literature documents can play a significant role in diversifying the economy, hence this study uses domestic credit to private sector percentage of GDP (FD) as a proxy of financial development. In addition, the literature argues that the thriving of the industrial economy sector and service sector creates more job opportunities for women in the formal job market. Therefore, explanatory variables of the study include industrial value addition and service value addition normalized (share) by GDP.

Econometric Methods and Hypothesis Development

The fundamental advantage of panel data and time-series data is that the panel estimator is benefitted from the combination of both data observations. The provided data can bring some advantages, such as heterogeneous inputs that lead to less collinearity among variables, more degrees of freedom, and more efficient results. The primary benefits of using a vast amount of data improve the efficiency of the parameter. The concern of similarities is a central issue. Meanwhile, providing the calculation by using large samples at a different time will increase the variability of sources.

In this study, the authors adopted two econometric techniques to investigate the two main variables, financial development and economic growth. Primarily, the panel data technique is based on fixed and random effect estimator, and MG, PMG, and DFE estimator of Pesaran and Smith (1995) and Pesaran et al. (1999).

\section{Unit-root Tests}

To examine the short-run and long-run impact of explanatory variables on economic growth, the authors tried to determine the existence of unit roots in the data series. In this case, the authors preferred the Pesaran, Shin, and Im, which is based on the wellknown Dickey-Fuller procedure. Im, Pesaran, and Shin, herein denoted as IPS, proposed a test for the presence of unit roots in panels that combine time series with the crosssection dimension; For the test to have power, fewer time observations are required. Since economics researchers found that IPS test has superior test power to analyze long-run relationships in panel data, hence, the authors employed this procedure in this study. IPS begins by spelling out a separate ADF regression for each cross-section with individual effects and no time trend. The advantage of IPS is that it uses separate unit root tests for the $\mathrm{N}$ cross-section units. Their test is based on the Augmented Dickey-fuller (ADF) statistics averaged across groups. When $\mathrm{N}$ and $\mathrm{T}$ are small, tests would have better performance (IPS, 1997).

\section{Dynamic Approaches}

This study applied the dynamic approach for assessing the impact of relevant determinants of female labor force participation. The objective of this study, first, is to locate the short and long-term correlation of women's participation with socioeconomic factors. Second, the authors attempted to estimate the 
differences between countries. Accordingly, the applicable technique is by using the Autoregressive Distributed Lag (ARDL). The use of ARDL, in turn, is to locate $(p, q)$ model for the standard error correction. The finding of ARDL, subsequently, is evaluated using the mean group (MG), as suggested by Pesaran and Smith (Pesaran \& Smith, 1995). As a result, the model for ARDL can be formulated as follows formula (Loayza \& Ranciere, 2005):

$$
\begin{aligned}
\Delta\left(y_{i}\right)_{\mathrm{t}}= & \sum_{j=1}^{p-1} \gamma_{\mathrm{j}}^{\mathrm{i}} \Delta\left(\mathrm{y}_{\mathrm{i}}\right)_{\mathrm{t}-\mathrm{j}}+\sum_{\mathrm{j}=0}^{\mathrm{q}-1} \delta_{\mathrm{j}}^{\mathrm{i}} \Delta\left(\mathrm{X}_{\mathrm{i}}\right)_{\mathrm{t}-\mathrm{j}}+\phi^{\mathrm{i}}\left[\left(\mathrm{y}_{\mathrm{i}}\right)_{\mathrm{t}-1}\right. \\
& \left.-\left\{\beta_{0}^{\mathrm{i}}+\beta_{1}^{\mathrm{i}}\left(\mathrm{X}_{\mathrm{i}}\right)_{\mathrm{t}-1}\right\}\right] \epsilon_{\mathrm{it}} \ldots . \text { equation } 1
\end{aligned}
$$

Where $y$ is the female labor force participation rate. $\mathrm{X}$ is a set of independent variables, e.g., education, compensation, number of the female labor force stock, ICT, and other mentioned tested variables. The notation of $\gamma$ expresses the short-run coefficient of dependent variables, on the one hand. On the other hand, ${ }^{\delta}$ denotes the short-run of the coefficient of independent variables. Both of these notations express the short-run estimation. At the same time, for expressing the long-run result, the authors used $\beta$ as the long-run coefficients. Similarly, $\varphi$ is the coefficient of the long-run adjustment. Moreover, the symbol of $i$ and $t$ is to signify countries and time.

The square brackets on the right side contain long-run growth regression. In order to determine the Equation (1), the authors used either PMG or MG or even DFE estimators. Those three models, as suggested by Demitriades and Law (Demetriades \& Law, 2006), are capable of calculating the long-run equilibrium. Herein, the authors could find the result of a cointegration test. In which, Pesaran and Smith (1995), Pesaran (1997), and Pesaran and Shin (1999) present the autoregressive distributed lag (ARDL) in the error correction form as a relatively new cointegration test. However, there remains a challenge to produce a consistent and efficient estimation for the long-run.

Although Johansen (1995); and Philipps \& Hansen (1990) explain that the colliding result in the long-run will occur due to the cointegration of related variables, on the contrary, Pesaran, and Shin (1999) refutes the claim. In turn, both provide evidence that their methods of PMG and MG can perform better than other estimations. In order to apply the PMG and MG methods for this study, firstly, the authors set aside the integration issues. Instead, the authors aimed to estimate the long-run correlation for finding the unit-roots. Accordingly, it can help the estimation process from different variables. The calculation results produce differences of stationarity ${ }^{1}$. Namely, it is valid whether the variables of interest are I (1) or I (0).

The Pooled Mean Group Estimator (PMG) of Pesaran et al. (1999)

The authors used the estimator of PMG in order to accommodate the differences from one country to another. While achieving the long-term calculation, the shortrun coefficients, such as intercepts and adjustment, is also part of the considered measurement. Meanwhile, in order to grasp with validity, consistency, and efficiency, there are a number of parameters. First, the long-run result of the correlation between

\footnotetext{
1 All data are either I(0) or I(1). When some variables are I(2) the estimations are not consistent. See Asteriou and Monastiriotis (2004)
} 
variables must not be less than -2 . Second, the consistency from PMG can be noted based on the error-correction model that is not related. The additional measurement can be drawn from $\operatorname{ARDL}(p, q)$, in which $p$ denotes the dependent variable and $q$ denotes the independent variables.

Third, the bias of the average estimation can be overcomed by using a large sample of $\mathrm{T}$ and $\mathrm{N}$. Accrodingly, Eberhardt and Teal (2010) suggest that the use of large sample can accommodate the heterogeneity that exists in the samples. At last, this estimator is helpful in some ways, especially when mirroring from the possibilities of input similarity from members of MENA countries. It can anticipate the long-run equilibrium correlations of income, technologies, to the openness of the economy.

\section{Dynamic Fixed Effect}

The dynamic FE estimator is similar to PMG in some ways. The model assists the exclusion of similar results of the coefficient in the short-run. While DFE computes the errorstandard, it also allows having intragroup correlation. Accordingly, the application of the model is also considered essential for detecting bias of endogeneity calculation, in which the bias often occurs between the error result and the lagged of the dependent variable. Nevertheless, the authors need to apply the Hausman test to detect the extent of endogeneity.

\section{Findings}

\section{Descriptive and Unit-root Test Result}

In this section, the study presents the result of descriptive statistics and unit root test results. Table 1 presents the correlation matrix as a result of the data analysis. As shown in the table below, female labor force participation is positively correlated with education, stock of females in the labor market, and the compensation package of the

Table 1. Correlation Matrix of Determinants of Female Labor Force Participation

\begin{tabular}{|c|c|c|c|c|c|c|c|c|c|c|c|}
\hline & FLP & FLF & EDU & Living & Capital & Copen & SGDP & IGDP & CREDIT & M2 & QOG \\
\hline FLP & 1.0000 & & & & & & & & & & \\
\hline FLF & 0.0440 & 1.0000 & & & & & & & & & \\
\hline EDU & 0.1213 & -0.0530 & 1.0000 & & & & & & & & \\
\hline Living & -0.0255 & 0.0952 & 0.4055 & 1.0000 & & & & & & & \\
\hline Capital & 0.0036 & 0.3267 & 0.5205 & 0.1571 & 1.0000 & & & & & & \\
\hline Copen & 0.2961 & -0.3523 & 0.0780 & 0.0283 & -0.1048 & 1.0000 & & & & & \\
\hline SGDP & -0.2695 & -0.2680 & 0.1019 & 0.0247 & 0.0438 & -0.1149 & 1.0000 & & & & \\
\hline IGDP & -0.2834 & 0.2883 & -0.1792 & -0.0448 & 0.0258 & -0.0974 & -0.2545 & 1.0000 & & & \\
\hline CREDIT & -0.3325 & -0.0145 & 0.0854 & 0.2464 & -0.0621 & -0.0508 & 0.3587 & 0.2711 & 1.0000 & & \\
\hline M2 & -0.4288 & -0.1271 & 0.0264 & 0.1202 & -0.1228 & -0.0746 & 0.4579 & 0.0526 & 0.8045 & 1.0000 & \\
\hline QOG & -0.0728 & -0.0573 & -0.1197 & -0.1697 & -0.1133 & 0.0205 & -0.0403 & -0.0447 & -0.0834 & -0.1008 & 1.0000 \\
\hline
\end{tabular}


labor force. However, it is negatively correlated with living costs, financial development, and quality of governance. It is also important to mention that these correlations, although provide critical understanding; nevertheless, there remain some explanations needed.

In order to gain overall information from the findings, the authors provided the unit root test results. The integration order can be achieved when the result of calculations is under I (1). It also implies that the result can help to determine the econometric model. Moreover, according to table 1 above, the estimation result validates the proposed variables (Pesaran, Pesaran, Shin, \& Smith, 1999). The validated of the hypothesis also goes hand in hand with other findings that support the importance of the tested variables.
The domestic values can undermine the participation rate (Hayo \& Caris, 2013), especially when there remain little incentives from the government. It, thus, implies that the structural factors remain important besides the social and cultural barriers.

At the same time, the study reports that under Maddala \& Wu (1999) accepts the null hypothesis of the presence of unit-root to the respect of the total number of residents variables. The finding implies that biomass is stationary at level. However, Maddala \& Wu (1999) tests reject the acceptance of the null hypothesis. Accordingly, it implies that all the variables of this study are stationary at first alteration formed. The results validate the suitability of the ARDL $(p, q)$ approach to be applied for analyzing the data.

Table 2. Panel Unit-root Test

\begin{tabular}{lllll}
\hline & \multicolumn{2}{c}{ Level } & \multicolumn{2}{c}{$1^{\text {st }}$ Difference } \\
\hline Female Labor Force & IPS & MW & IPS & MW \\
Participation & -1.503 & -1.197 & $-3.146^{* * *}$ & $-17.452^{* * *}$ \\
Female Labor Force & -1.368 & $-2.837^{* * *}$ & $-3.184^{* * *}$ & $-33.209^{* * *}$ \\
Education & -1.506 & -0.834 & $-2.652^{* * *}$ & $-3.438^{* * *}$ \\
Cost Of Living & -1.382 & 2.236 & $-2.486^{* * *}$ & $-6.208^{* * *}$ \\
Capital Stock & -1.503 & -1.197 & $-3.146^{* * *}$ & $-17.452^{* * *}$ \\
Compensation & -1.368 & $-2.837^{* * *}$ & $-3.184^{* * *}$ & $-33.209^{* * *}$ \\
IGDP & -1.506 & -0.834 & $-2.652^{* * *}$ & $-3.438^{* * *}$ \\
SGDP & -1.252 & 2.236 & $-2.386^{* * *}$ & $-6.218^{* * *}$ \\
Credit & -1.521 & -1.191 & $-3.146^{* * *}$ & $-17.352^{* * *}$ \\
M2 & -1.316 & -0.932 & $-2.652^{* * *}$ & $-3.538^{* * *}$ \\
Quality of Governance & -1.372 & 2.236 & $-2.586^{* * *}$ & $-6.338^{* * *}$ \\
ICT & -1.513 & -1.197 & $-3.246^{* * *}$ & $-17.352^{* * *}$ \\
\hline
\end{tabular}

Note: ${ }^{* * *},{ }^{* *}$ and ${ }^{*}$ indicate $1 \%, 5 \%$, and $10 \%$ significance level. Panel Unit-root Test by using IPS: Im, Pesaran \& Shin (2003) and MW: Maddala \& Wu (1999). 
Anas Abdulrahman Almiman, Aris Chandra Pradikta, and Raeef Altamimi

Table 3. Women and Work in MENA Economies - Baseline Model

\begin{tabular}{|c|c|c|c|c|c|c|}
\hline & PMG & & MG & & DFE & \\
\hline Variables & Long Run & Short Run & $\begin{array}{l}\text { Long } \\
\text { Run }\end{array}$ & $\begin{array}{l}\text { Short } \\
\text { Run }\end{array}$ & $\begin{array}{l}\text { Long } \\
\text { Run }\end{array}$ & Short Run \\
\hline \multirow[t]{2}{*}{ Error Correction } & & $-0.0521^{* * *}$ & & $-0.559^{* * *}$ & & $-0.0167^{*}$ \\
\hline & & $(0.0185)$ & & $(0.0701)$ & & $(0.0097)$ \\
\hline \multirow{2}{*}{$\begin{array}{l}\Delta \text { Female Labor } \\
\text { Force }\end{array}$} & & $0.917^{* * *}$ & & $0.954^{* * *}$ & & $1.017^{* * *}$ \\
\hline & & $(0.0968)$ & & $(0.0827)$ & & $(0.0234)$ \\
\hline \multirow[t]{2}{*}{$\Delta$ Education } & & 0.189 & & 0.339 & & -0.00677 \\
\hline & & $(0.147)$ & & $(0.308)$ & & $(0.0393)$ \\
\hline \multirow[t]{2}{*}{$\Delta$ Cost of Living } & & 0.0166 & & -0.0219 & & 0.00125 \\
\hline & & $(0.0238)$ & & $(0.0183)$ & & $(0.00858)$ \\
\hline \multirow[t]{2}{*}{$\Delta$ Capital Stock } & & -0.00220 & & -0.0127 & & $0.0198^{* * *}$ \\
\hline & & $(0.00671)$ & & $(0.0246)$ & & $(0.0067)$ \\
\hline \multirow[t]{2}{*}{$\Delta$ Compensation } & & -0.00516 & & 0.0306 & & $-0.0378^{*}$ \\
\hline & & $(0.0316)$ & & $(0.0396)$ & & $(0.0203)$ \\
\hline \multirow{2}{*}{$\begin{array}{l}\text { Female Labor } \\
\text { Force }\end{array}$} & $0.555^{\star * *}$ & & $1.173^{* * *}$ & & $1.417^{* * *}$ & \\
\hline & $(0.0499)$ & & $(0.248)$ & & $(0.440)$ & \\
\hline \multirow[t]{2}{*}{ Education } & $-0.240^{* * *}$ & & -0.00322 & & -0.699 & \\
\hline & $(0.0319)$ & & $(0.159)$ & & $(0.477)$ & \\
\hline \multirow[t]{2}{*}{ Cost of Living } & $0.111^{* * *}$ & & $-0.0917^{*}$ & & 0.511 & \\
\hline & $(0.0261)$ & & $(0.0516)$ & & $(0.371)$ & \\
\hline \multirow[t]{2}{*}{ Capital Stock } & $0.0868^{* \star *}$ & & $0.0993^{*}$ & & $0.274^{*}$ & \\
\hline & $(0.00944)$ & & $(0.0525)$ & & $(0.161)$ & \\
\hline \multirow[t]{2}{*}{ Compensation } & $-0.285^{* *}$ & & 0.351 & & -2.517 & \\
\hline & $(0.115)$ & & $(0.274)$ & & $(1.646)$ & \\
\hline \multirow[t]{2}{*}{ Constant } & & $0.0620^{* * *}$ & & $-0.707^{*}$ & & -0.0278 \\
\hline & & $(0.0226)$ & & $(0.371)$ & & $(0.0195)$ \\
\hline Observations & 816 & 816 & 816 & 816 & 816 & 816 \\
\hline Hausman Test & 2.80 & 0.731 & & & & \\
\hline Hausman Test & 1.51 & 0.803 & & & & \\
\hline
\end{tabular}


The result of the above calculation can be explained in several hypotheses. The subsequent sections will explain by first comparing the women and work through the baseline model. Furthermore, the authors analyzed further the result of tested variables and hypotheses afterward.

\section{Women and Work- Baseline Model}

Inthebaselinemodel, theauthorsconsidered education as a core element of female labor force participation. Several studies argue that education and skill level of the women create an opportunity to leave home and participate in the formal job market (Abramo \& Valenzuela, 2005; Apps \& Rees, 2001; Engelhardt \& Prskawetz, 2004). However, this hypothesis is nullified (as an insignificant coefficient in Table 5.3) in the context of Saudi Arabia because the oil-dependent economy that produces a staggering 26.9 percent of female unemployment (Al Munajjed, 2010), and 78.8 percent of these are universityeducated women (Welsh et al., 2014).

In this study, women may also give up the decision to be a staying-home person and go out for work to cover the basic living cost (Haas et al., 2006). For example, the rise of essential necessities over the past few decades have influenced the pattern and dynamics of them. In the context of the continuous increase in living costs, women may engage in the formal labor market for supporting the family needs (Elson, 1999). For example, Haas et al. (2006) demonstrate that the economic necessity makes many women in less prosperous countries work full time. Thus, the authors argued, other things remaining the same, an increase in living cost should push the women to engage in labor force participation.

The prior section argues that women decisions to stay at home or join in the formal labor market is under some conditions - where the authors selected prime four regressors concerning with scenario of the Saudi labor market, e.g., total female labor force, oil rent per capita, education, and cost of living. The dynamic impact of those core regressors on the female labor force participation rate is present in Table 3. Thus, the baseline model examines three hypotheses.

This study applies three estimators of panel ARDL framework, e.g. PMG, MG, and DFE. The authors focused on PMG as the Hausman test confirms the efficiency and consistency of PMG estimator over MG and DFE. Such finding indicates that the short-run parameters of the estimation follow a heterogonous nature, while long-run parameters follow a homogenous nature. The coefficient errorcorrection term is negative significant. As the study applies the dynamic framework, the authors also found the presence of short of disequilibrium in which it emerges as a result of various exogenous shocks. Thus, the authors observed that the low economic adjustment rate is significant. The estimated coefficient of the error correction (EC) of PMG estimator is -0.0521 , which implies that the converge towards the long-run equilibrium takes place with a to 5.21 percent adjustment per year after an economic shock, also confirming a long run, the co-integrating relationship among the variables in the baseline model.

The first hypothesis is to assess whether or not the education is positively linked with female labor force participation in MENA economies. In the baseline model, this study considered education as a core determinant of female labor force participation. Several studies argue that education and skill level of the women create an opportunity to leave home and participate in the formal job market. 
The coefficient of education found to be a positive and significant indication that education is promoting women of MENA countries to participate in the formal job market in the long run. The finding coincides with the argument of (Abramo \& Valenzuela, 2005; Apps \& Rees, 2001; Engelhardt \& Prskawetz, 2004). However, Table 3 also documents that education insignificantly fosters women's participation in the labor force.

The second hypothesis shows the cost of living fosters female labor force participation from MENA countries. Women would also give up the decision to stay at home and go out for work due to the increase of basic living cost necessity (Haas et al., 2006). In an ever-increasing living cost context, women are available as an alternative of men to complement the total household income (Elson, 1999). For example, Haas et al. (2006) demonstrate that the economic necessity for many women in less prosperous countries is by working full-time. Thus, in the argues that other things remaining the same, an increase in living cost should push the women to engage in labor force participation.

The third hypothesis of this study argues that capital stocks foster female labor force participation by creating more opportunities to work. However, the capital stock would have either a positive or negative impact on women's participation in the job market in which it depends on the substitution effect and complementary effect. Although, simple classical growth theory suggests that finance and labor can both be complimentary and as well as a substitute. The result shows that capital stock is positively and significantly associated with female labor force participation in the long run, while insignificantly associated in the short run. Thus, this finding implies that capital stock's complementary effect is higher than the substitute effect in MENA economies.

Compensation is the core endogenous variable of labor demand and supply. Theoretically, the demand for labor is negatively associated with wage or compensation while positively associated labor supply due to two reasons. First, a rise in the wage rate increases the costs of firms producing the commodity, forcing them to raise their selling prices. As the price of the product rises, consumers will buy less of it, and less output will be produced and sold. The assumption implies that less labor will be used. Second, since a rise in wages makes labor more expensive about capital, firms will substitute capital for labor. This means that less labor will be used to produce any output of the firms in the industry sell. Table 3 shows that compensation is negatively and significantly linked to the female labor participation rate in the long run, which means a higher rate of compensation lowers the job opportunity for women. However, compensation has an insignificant impact on female labor force participation in the short run.

\section{Women and Work - Role of Industrialization}

Since the 1990s, the global development agenda makes many developing countries focus on the transformation of the economy. It aims to shifts the industrial characteristics from agriculture to the industry with service- 
oriented activities. Scholars argue that the change can take effect on women's participation in the labor market (Pampel \& Tanaka, 1986). Nevertheless, evidence shown by Haghighat (2002) gives another suggestion in which the transformation remains to possess some challenges for women. The research result also implies that an industrial type such as the service sector has a better determinant for job absorption than factories. Similarly,
Rendall (2012) argues that the tax differences in various industries can make women either work in the service sector or remain to stay at home. At the same time, Kucera and Tejani (2014) underscore the export-oriented manufacturing sector that goes hand in hand with the feminization of the labor force. Accordingly, these previous findings help to formulate another hypothesis that industrialization foster the female labor force participation.

Table 4. Women and Work in MENA Countries - Role of Industrialization

\begin{tabular}{|c|c|c|c|c|c|c|}
\hline \multirow{2}{*}{ Variables } & \multicolumn{3}{|c|}{ PMG } & \multicolumn{2}{|l|}{ MG } & \multirow{2}{*}{$\begin{array}{r}\text { DFE } \\
\text { Short Run }\end{array}$} \\
\hline & $\begin{array}{l}\text { Long } \\
\text { Run }\end{array}$ & $\begin{array}{r}\text { Short } \\
\text { Run } \\
\end{array}$ & Long Run & Variables & Long Run & \\
\hline \multirow[t]{2}{*}{ Error Correction } & & $-0.232^{* * *}$ & & -0.00252 & & $-0.0582^{* * *}$ \\
\hline & & $(0.0459)$ & & $(0.00218)$ & & $(0.0045)$ \\
\hline \multirow[t]{2}{*}{ Female labor force } & & $0.906^{* * *}$ & & $0.875^{* * *}$ & & $0.947^{* * *}$ \\
\hline & & $(0.0871)$ & & $(0.0819)$ & & (0.0195) \\
\hline \multirow[t]{2}{*}{ Education } & & -0.0577 & & 0.0476 & & 0.0112 \\
\hline & & $(0.0842)$ & & $(0.107)$ & & $(0.0292)$ \\
\hline \multirow[t]{2}{*}{ Cost of living } & & 0.00204 & & -0.00281 & & 0.000529 \\
\hline & & $(0.0138)$ & & $(0.00805)$ & & $(0.00279)$ \\
\hline \multirow[t]{2}{*}{ Capital stock } & & 0.000651 & & -0.00702 & & $0.0155^{* * *}$ \\
\hline & & $(0.0085)$ & & $(0.0136)$ & & $(0.0046)$ \\
\hline \multirow[t]{2}{*}{ IGDP } & & -0.00265 & & 0.000892 & & -0.0006 \\
\hline & & $(0.00375)$ & & $(0.00405)$ & & $(0.00289)$ \\
\hline \multirow[t]{2}{*}{ Female labor force } & 0.0858 & & $1.506^{* *}$ & & $0.926^{* * *}$ & \\
\hline & $(0.428)$ & & $(0.594)$ & & $(0.0560)$ & \\
\hline \multirow[t]{2}{*}{ Education } & $-1.502^{* * *}$ & & -0.425 & & -0.0663 & \\
\hline & $(0.504)$ & & $(0.748)$ & & $(0.0442)$ & \\
\hline \multirow[t]{2}{*}{ Cost of living } & $-0.280^{* *}$ & & -0.315 & & $0.0871^{* *}$ & \\
\hline & $(0.141)$ & & $(0.323)$ & & $(0.0433)$ & \\
\hline \multirow[t]{2}{*}{ Capital stock } & $0.452^{* * *}$ & & -0.264 & & $0.0760^{* * *}$ & \\
\hline & $(0.158)$ & & $(0.346)$ & & $(0.0148)$ & \\
\hline \multirow[t]{2}{*}{ IGDP } & $1.226^{* * *}$ & & 0.0796 & & -0.0193 & \\
\hline & $(0.373)$ & & $(0.109)$ & & $(0.0242)$ & \\
\hline \multirow[t]{2}{*}{ Constant } & & -0.0033 & & -0.259 & & -0.0117 \\
\hline & & $(0.0069)$ & & $(0.241)$ & & $(0.0132)$ \\
\hline Observations & 1,428 & 1,428 & 1,428 & 1,428 & 1,428 & 1,428 \\
\hline Hausman Test & 2.82 & 0.721 & & & & \\
\hline Hausman Test & 1.41 & 0.833 & & & & \\
\hline
\end{tabular}


The result presented in Table 4 shows a positive and significant coefficient of industrial value addition (IGDP). The result indicates that thrive of industrial value addition fosters female labor force participation in the long run. At the same time, it insignificantly affects in the short run. Industrialization fosters economic openness. The condition makes the country to readjust the economic strategies

Table 5. Women and Work in MENA Economies - Role of Service Sector

\begin{tabular}{|c|c|c|c|c|c|c|}
\hline \multirow[b]{2}{*}{ Variables } & \multicolumn{3}{|c|}{ PMG } & \multicolumn{2}{|l|}{ MG } & \multirow{2}{*}{$\begin{array}{r}\text { DFE } \\
\text { Long Run }\end{array}$} \\
\hline & $\begin{array}{l}\text { Long } \\
\text { Run }\end{array}$ & $\begin{array}{r}\text { Short } \\
\text { Run }\end{array}$ & $\begin{array}{r}\text { Long } \\
\text { Run } \\
\end{array}$ & Long Run & Short Run & \\
\hline \multirow[t]{2}{*}{ Error Correction } & & $-0.560^{* * *}$ & & -0.0028 & & $-0.0190^{*}$ \\
\hline & & $(0.0681)$ & & $(0.0043)$ & & $(0.0106)$ \\
\hline \multirow[t]{2}{*}{ Female labor force } & & $0.942^{* * *}$ & & $0.976^{* * *}$ & & $1.018^{* * *}$ \\
\hline & & $(0.0943)$ & & $(0.0871)$ & & $(0.0238)$ \\
\hline \multirow[t]{2}{*}{ Education } & & $-0.158^{* *}$ & & 0.325 & & -0.0334 \\
\hline & & $(0.0770)$ & & $(0.347)$ & & $(0.0403)$ \\
\hline \multirow[t]{2}{*}{ Cost of living } & & -0.00440 & & -0.0209 & & -0.000662 \\
\hline & & $(0.00520)$ & & $(0.0160)$ & & $(0.00943)$ \\
\hline \multirow[t]{2}{*}{ Capital stock } & & 0.0108 & & -0.00687 & & $0.0216^{* * *}$ \\
\hline & & $(0.00879)$ & & $(0.0194)$ & & $(0.00692)$ \\
\hline \multirow[t]{2}{*}{ Compensation } & & 0.0219 & & 0.0410 & & $-0.0361^{*}$ \\
\hline & & $(0.0307)$ & & $(0.0465)$ & & $(0.0206)$ \\
\hline \multirow[t]{2}{*}{ SGDP } & & 0.00431 & & $0.0164^{* *}$ & & 0.00684 \\
\hline & & $(0.0106)$ & & $(0.00747)$ & & $(0.00444)$ \\
\hline \multirow[t]{2}{*}{ Female labor force } & $1.346^{\star * *}$ & & $1.323^{\star * *}$ & & $1.129^{\star * *}$ & \\
\hline & $(0.312)$ & & $(0.252)$ & & $(0.357)$ & \\
\hline \multirow[t]{2}{*}{ Education } & $-0.973^{* *}$ & & 0.102 & & -0.464 & \\
\hline & $(0.394)$ & & $(0.163)$ & & $(0.353)$ & \\
\hline \multirow{2}{*}{ Cost of living } & 0.0838 & & -0.0669 & & 0.400 & \\
\hline & $(0.130)$ & & $(0.0536)$ & & $(0.313)$ & \\
\hline \multirow[t]{2}{*}{ Capital stock } & $0.384^{* * *}$ & & 0.0344 & & $0.252^{*}$ & \\
\hline & $(0.123)$ & & $(0.0241)$ & & $(0.140)$ & \\
\hline \multirow[t]{2}{*}{ Compensation } & $1.365^{* *}$ & & $0.546^{*}$ & & -2.388 & \\
\hline & $(0.657)$ & & $(0.310)$ & & $(1.495)$ & \\
\hline \multirow[t]{2}{*}{ SGDP } & $2.837^{* *}$ & & -0.0545 & & -0.527 & \\
\hline & $(1.111)$ & & $(0.0447)$ & & $(0.332)$ & \\
\hline \multirow[t]{2}{*}{ Constant } & & 0.0237 & & -0.481 & & 0.0190 \\
\hline & & $(0.0327)$ & & $(0.350)$ & & $(0.0255)$ \\
\hline Observations & 768 & 768 & 768 & 768 & 768 & 768 \\
\hline Hausman Test & 1.80 & 0.832 & & & & \\
\hline Hausman Test & 1.51 & 0.841 & & & & \\
\hline
\end{tabular}


and to include women to fill the demand in the labor market (Moghadam, 2005). Furthermore, as industrialization takes place, it also increases the mobility of the population. Although it may not always be the case for the Muslim majority countries (Robinson, 2015), nevertheless, the restrictions and social values can change, in the long run. As a result, it also brings the effect of industrialization.

The effect of industrialization in some high-income MENA countries can be noticed through a high degree of human mobilities and industrial diversification. In UAE, for instance, while some industries are filled with foreign labor forces, the absorption of women in the formal labor market makes up a third from the total employment (Schilirò, 2013). Furthermore, some occupations, such as education, medics, and technology-related sectors, are among the choices of highly educated women. It, thus, also suggests the role service sector besides the development in the industry.

Women and Work - Role of the Service Sector

Previous literature argued that the development of service sectors create more job opportunity. For example, the establishment of a stock market, the launch of financial institutions, and the sharp rise of insurance companies have produced increased avenues for women in banking, business services, telecommunication, and education fields. The finding is also shown in the result in Table 5. A positive and significant coefficient of service sector development indicates that the thrive of the service sector has a positive linkage with female labor-force participation in the context of MENA countries. However, the short-term coefficient of service sector development is positive yet insignificant, which refers to the service sector GDP is not promoting female labor-force participation in the short run.

The emerging service industry brings more occupational choices for women to participate in the formal job market. The short-term effect does not significantly affect participation due to some considerations. The previous report shows that women's participation is also affected by the incentive to enter the labor market (Altuzarra et al., 2019). Meanwhile, the available incentive can take time to overcome the structural barriers. The structural barriers encompass the changing of some laws. Meanwhile, the changing of the political sphere in many Arab countries is often going slowly due to the dictatorial and oligarch political structure.

In addition, the presented calculation in Table 5 shows a positive and significant coefficient of service value addition (IGDP) on women's work participation in Middle East countries. The result indicates that the thrive of service sectors affects the female labor force in the long run, while it insignificantly affects in the short term.

Women and Work - The Role of Financial Development

This study also tested the seventh hypothesis of whether financial development promotes female labor participation or not in MENA economies? The prior section argues that financial development would have a role in explaining female labor force participation. Thus, the authors considered the role of it in a setup. Table 6 represents the financial development, and the female labor force is insignificantly correlated in the short run and long run. It could be speculated that 
the level of financial development in Middle East countries yet to be improved to pose a significant relation with female labor force participation. Also, due to poor institutional quality (Bhattacharyya \& Hodler, 2014), it also compromises the goal of diversifying the economy. Thus, it may not significantly influence female labor force participation.

The result presented in Table 6 shows a negative and insignificant coefficient of

Table 6. Women and Work in MENA Economies - Role of Credit Disbursement

\begin{tabular}{|c|c|c|c|c|c|c|}
\hline & & PMG & & MG & & DFE \\
\hline Variables & $\begin{array}{r}\text { Long } \\
\text { Run }\end{array}$ & Short Run & $\begin{array}{r}\text { Long } \\
\text { Run }\end{array}$ & Variables & $\begin{array}{r}\text { Long } \\
\text { Run }\end{array}$ & Short Run \\
\hline Error Correction & & $\begin{array}{c}-0.662^{* * *} \\
(0.0899)\end{array}$ & & $\begin{array}{r}-0.00936 \\
(0.00617)\end{array}$ & & $\begin{array}{r}-0.0157 \\
(0.0100)\end{array}$ \\
\hline Female labor force & & $\begin{array}{l}0.918^{* * *} \\
(0.0872)\end{array}$ & & $\begin{array}{r}0.994^{* * *} \\
(0.102)\end{array}$ & & $\begin{array}{l}1.017^{* * *} \\
(0.0238)\end{array}$ \\
\hline Education & & $\begin{array}{r}0.177 \\
(0.159)\end{array}$ & & $\begin{array}{r}0.345 \\
(0.294)\end{array}$ & & $\begin{array}{r}-0.0101 \\
(0.0402)\end{array}$ \\
\hline Cost of living & & $\begin{array}{r}-0.00747 \\
(0.00953)\end{array}$ & & $\begin{array}{r}-0.0198 \\
(0.0210)\end{array}$ & & $\begin{array}{c}0.000764 \\
(0.00877)\end{array}$ \\
\hline Capital stock & & $\begin{array}{r}0.00789 \\
(0.00712)\end{array}$ & & $\begin{array}{r}-0.0155 \\
(0.0287)\end{array}$ & & $\begin{array}{l}0.0203^{* * *} \\
(0.00683)\end{array}$ \\
\hline Compensation & & $\begin{array}{r}0.0280 \\
(0.0292)\end{array}$ & & $\begin{array}{r}0.0438 \\
(0.0497)\end{array}$ & & $\begin{array}{l}-0.0378^{*} \\
(0.0207)\end{array}$ \\
\hline Credit & & $\begin{array}{r}0.0005 \\
(0.0001)\end{array}$ & & $\begin{array}{r}-0.00001 \\
(0.00025)\end{array}$ & & $\begin{array}{r}0.0003 \\
(0.0001)\end{array}$ \\
\hline Female labor force & $\begin{array}{r}0.798^{* * *} \\
(0.198)\end{array}$ & & $\begin{array}{r}1.542^{* * *} \\
(0.342)\end{array}$ & & $\begin{array}{r}1.486^{* * *} \\
(0.517)\end{array}$ & \\
\hline Education & $\begin{array}{r}-1.911^{* * *} \\
(0.565)\end{array}$ & & $\begin{array}{c}-0.142 \\
(0.229)\end{array}$ & & $\begin{array}{c}-0.754 \\
(0.559)\end{array}$ & \\
\hline Cost of living & $\begin{array}{r}1.204^{* * *} \\
(0.374)\end{array}$ & & $\begin{array}{l}-0.0935 \\
(0.0865)\end{array}$ & & $\begin{array}{r}0.579 \\
(0.456)\end{array}$ & \\
\hline Capital stock & $\begin{array}{r}0.721^{* * *} \\
(0.207)\end{array}$ & & $\begin{array}{r}0.169 \\
(0.113)\end{array}$ & & $\begin{array}{r}0.294 \\
(0.188)\end{array}$ & \\
\hline Compensation & $\begin{array}{r}-1.855^{* * *} \\
(0.575)\end{array}$ & & $\begin{array}{r}0.399 \\
(0.496)\end{array}$ & & $\begin{array}{r}-2.655 \\
(1.868)\end{array}$ & \\
\hline Credit & $\begin{array}{r}-0.0013 \\
(0.00179)\end{array}$ & & $\begin{array}{r}-0.00094 \\
(0.00085)\end{array}$ & & $\begin{array}{r}-0.0022 \\
(0.00374)\end{array}$ & \\
\hline Constant & & $\begin{array}{r}-0.0386 \\
(0.0240)\end{array}$ & & $\begin{array}{l}-1.024 \\
(0.632)\end{array}$ & & $\begin{array}{r}-0.0295 \\
(0.0201)\end{array}$ \\
\hline Observations & 792 & 792 & 792 & 792 & 792 & 792 \\
\hline Hausman Test & 2.87 & 0.723 & & & & \\
\hline Hausman Test & 1.54 & 0.812 & & & & \\
\hline
\end{tabular}


financial development proxied by credit disbursement in the private sector on female labor participation. This result coincides with the fact that the financial sectors in most Middle East countries are underdeveloped and yet to unleash the positive effect of the financial sectors in the labor market, especially in the women's participation in the job market.
The sole financial help has limitations to explain women's participation due to the complex social fabric (Bastian et al., 2018). According to them, some multilevel factors from micro to macro influence the positive correlations between financial help and women's participation in the labor market. In the realm of entrepreneurial activities, the micro aspect can be a lack

Table 7. Women and Work in MENA Economies - Role of Money Supply

\begin{tabular}{|c|c|c|c|c|c|c|}
\hline \multirow[b]{2}{*}{ Variables } & \multicolumn{3}{|c|}{ PMG } & \multicolumn{2}{|l|}{ MG } & \multirow{2}{*}{$\begin{array}{r}\text { DFE } \\
\text { Short Run }\end{array}$} \\
\hline & $\begin{array}{l}\text { Long } \\
\text { Run }\end{array}$ & Short Run & $\begin{array}{r}\text { Long } \\
\text { Run }\end{array}$ & Variables & Long Run & \\
\hline \multirow[t]{2}{*}{ Error Correction } & & -0.00313 & & $-0.335^{* * *}$ & & $-0.0554^{* * *}$ \\
\hline & & $(0.00743)$ & & $(0.0596)$ & & $(0.00490)$ \\
\hline \multirow[t]{2}{*}{ Female labor force } & & $0.866^{* * *}$ & & $0.886^{* * *}$ & & $0.937^{* * *}$ \\
\hline & & $(0.0837)$ & & (0.0799) & & $(0.0210)$ \\
\hline \multirow[t]{2}{*}{ Education } & & 0.0732 & & 0.0261 & & -0.00945 \\
\hline & & $(0.0915)$ & & $(0.101)$ & & $(0.0332)$ \\
\hline \multirow[t]{2}{*}{ Cost of living } & & 0.00068 & & -0.0096 & & 0.000760 \\
\hline & & $(0.0168)$ & & $(0.0114)$ & & $(0.00294)$ \\
\hline \multirow[t]{2}{*}{ Capital stock } & & 0.0119 & & 0.0118 & & $0.0154^{* * *}$ \\
\hline & & $(0.0121)$ & & $(0.0120)$ & & $(0.00491)$ \\
\hline \multirow[t]{2}{*}{ M2 } & & -0.0002 & & -0.0005 & & -0.0005 \\
\hline & & $(0.0004)$ & & $(0.0006)$ & & $(0.0005)$ \\
\hline \multirow[t]{2}{*}{ Female labor force } & $0.345^{* * *}$ & & -0.217 & & $0.925^{\star * *}$ & \\
\hline & $(0.0828)$ & & $(1.217)$ & & $(0.0639)$ & \\
\hline \multirow[t]{2}{*}{ Education } & $0.590^{* * *}$ & & -6.178 & & -0.0539 & \\
\hline & $(0.0767)$ & & $(6.851)$ & & $(0.0528)$ & \\
\hline \multirow[t]{2}{*}{ Cost of living } & $0.348^{* * *}$ & & -0.910 & & $0.113^{* *}$ & \\
\hline & $(0.0421)$ & & (1.339) & & $(0.0486)$ & \\
\hline \multirow[t]{2}{*}{ Capital stock } & $0.386^{* * *}$ & & 3.643 & & $0.0937^{* * *}$ & \\
\hline & $(0.040)$ & & (3.345) & & $(0.0178)$ & \\
\hline \multirow[t]{2}{*}{ M2 } & -0.0004 & & -0.002 & & $-0.00139^{* *}$ & \\
\hline & $(0.0005)$ & & $(0.0042)$ & & $(0.0005)$ & \\
\hline \multirow[t]{2}{*}{ Constant } & & -0.0220 & & -0.103 & & $-0.0240^{*}$ \\
\hline & & $(0.0428)$ & & $(0.282)$ & & $(0.0130)$ \\
\hline Observations & 1,296 & 1,296 & 1,296 & 1,296 & 1,296 & 1,296 \\
\hline Hausman Test & 2.83 & 0.729 & & & & \\
\hline Hausman Test & 1.53 & 0.813 & & & & \\
\hline
\end{tabular}


of motivation. Meanwhile, the broader aspects encompass the difficulties of accessing credit without husband permission and the limitation of sectors allowed for women to explore the market opportunities.
Likewise, the result presented in Table 7 also shows a negative and insignificant coefficient of financial development proxied by money supply on female labor participation. This result coincides with the fact that the financial sectors in most Middle East countries

Table 8. Women and Work in MENA Economies - Role of Governance

\begin{tabular}{|c|c|c|c|c|c|c|}
\hline \multirow[b]{2}{*}{ Variables } & \multicolumn{2}{|c|}{ PMG } & \multicolumn{2}{|c|}{ MG } & \multicolumn{2}{|c|}{ DFE } \\
\hline & $\begin{array}{l}\text { Long } \\
\text { Run }\end{array}$ & $\begin{array}{r}\text { Short } \\
\text { Run }\end{array}$ & $\begin{array}{r}\text { Long } \\
\text { Run }\end{array}$ & Variables & $\begin{array}{r}\text { Long } \\
\text { Run }\end{array}$ & Short Run \\
\hline \multirow[t]{2}{*}{ Error Correction } & & $-0.408^{* * *}$ & & -0.0101 & & $-0.0768^{* * *}$ \\
\hline & & $(0.0591)$ & & $(0.0139)$ & & $(0.0102)$ \\
\hline \multirow[t]{2}{*}{ Female labor force } & & $0.993^{* * *}$ & & $0.647^{* * *}$ & & $0.654^{* * *}$ \\
\hline & & $(0.247)$ & & $(0.228)$ & & $(0.0445)$ \\
\hline \multirow[t]{2}{*}{ Education } & & 0.122 & & 0.136 & & 0.0431 \\
\hline & & $(0.158)$ & & $(0.165)$ & & $(0.0630)$ \\
\hline \multirow[t]{2}{*}{ Cost of living } & & 0.0167 & & 0.00528 & & -0.00553 \\
\hline & & $(0.0142)$ & & $(0.0121)$ & & $(0.0140)$ \\
\hline \multirow[t]{2}{*}{ Capital stock } & & 0.00276 & & -0.0308 & & 0.00395 \\
\hline & & $(0.00715)$ & & $(0.0343)$ & & $(0.0112)$ \\
\hline \multirow[t]{2}{*}{ Compensation } & & 0.0190 & & 0.000879 & & 0.0410 \\
\hline & & $(0.0190)$ & & $(0.0313)$ & & $(0.0336)$ \\
\hline \multirow{2}{*}{$\begin{array}{l}\text { Quality of } \\
\text { Governance }\end{array}$} & & 0.0307 & & -0.0129 & & $-0.113^{*}$ \\
\hline & & $(0.0480)$ & & $(0.0543)$ & & $(0.0581)$ \\
\hline \multirow[t]{2}{*}{ Female labor force } & $-0.420^{* * *}$ & & $0.530^{* *}$ & & $0.170^{* *}$ & \\
\hline & $(0.0854)$ & & $(0.270)$ & & $(0.0761)$ & \\
\hline \multirow[t]{2}{*}{ Education } & $0.281^{* * *}$ & & -0.439 & & 0.154 & \\
\hline & $(0.0649)$ & & $(0.407)$ & & $(0.106)$ & \\
\hline \multirow[t]{2}{*}{ Cost of living } & $0.138^{* \star *}$ & & 0.0365 & & $-0.299^{* * *}$ & \\
\hline & $(0.0283)$ & & $(0.0815)$ & & $(0.0975)$ & \\
\hline \multirow[t]{2}{*}{ Capital stock } & $0.0507^{* *}$ & & 0.0167 & & $0.0509^{*}$ & \\
\hline & $(0.0253)$ & & $(0.0502)$ & & $(0.0280)$ & \\
\hline \multirow[t]{2}{*}{ Compensation } & $-0.440^{* * *}$ & & -0.252 & & 0.261 & \\
\hline & $(0.114)$ & & $(0.169)$ & & $(0.267)$ & \\
\hline \multirow{2}{*}{$\begin{array}{l}\text { Quality of } \\
\text { Governance }\end{array}$} & $0.491^{* * *}$ & & 0.295 & & $1.096^{* * *}$ & \\
\hline & $(0.0895)$ & & $(0.525)$ & & $(0.406)$ & \\
\hline \multirow[t]{2}{*}{ Constant } & & 0.0585 & & $-3.402^{*}$ & & -0.0552 \\
\hline & & $(0.142)$ & & $(1.827)$ & & $(0.0781)$ \\
\hline Observations & 816 & 816 & 816 & 816 & 816 & 816 \\
\hline Hausman Test & 2.80 & 0.731 & & & & \\
\hline Hausman Test & 1.51 & 0.803 & & & & \\
\hline
\end{tabular}


are underdeveloped and yet to unleash the positive effect of the financial sectors for women's participation in the labor market.

Women and Work in Economies - Role of Governance

Several studies, e.g., King and Levine (1993), Demirguc-Kunt and Maksimovic (1998), argued the quality of governance plays a key role in economic development which motivates to scrutinize the impact of the quality of governance in female labor force participation. Table 9 below reports the quality of governance positively and significantly promotes female labor force participation in the long run, while it plays an insignificant role in the short run. Good governance can induce female labor participation in some ways. Accordingly, the significant roles of gendersensitive policies help to facilitate women to balance between work and taking care of the family. Nevertheless, although some countries have been progressing toward the gender-sensitive policy, there remain some challenges among less developed countries within MENA.

\section{Conclusion}

This study highlights several findings. First, in Muslim majority countries, the female employment rate has not been spurred by governance, both in the short or the long run. Second, financial development, either measured by credit disbursement or money supply, does not affect the female participation in the labor market. Third, service GDP and industrial GDP affect the growth of the labor force in the labor market. More importantly, this study failed to find any evidence that education can positively affect labor participation for women. However, educational attainment can improve the possibilities of women entering labor forces.

The negative correlations between educational attainments and labor force participation are evidence that requires further study. Moreover, it also explains some misconceptions about the Middle East and North Africa countries' treatment of women. For example, if social institutions, such as religion, would have been critical barriers of women empowerment in the labor market based on educational restrictions, this study should find a positive link between education and women's labor force participation. However, education has a negative and insignificant correlation. The most critical determinants in the rule of law and most of the Middle East and North Africa countries are that they remain under the dictatorial or pseudo-dictatorial regime. Again, this study found that a transformation of the economy towards industrialization and service economy positively affects women's labor participation in the job market. In summary, this study also suggests that MENA countries should improve the political conditions, including the rule of law, and transform to industrialization to foster economic outcomes.

\section{References}

AlMunajjed, M. (2010). Women's employment in Saudi Arabia: A major challenge. New York City: Booz \& Company.

Abramo, L., \& Valenzuela, M. E. (2005). Women's labour force participation rates in Latin America. International Labour Review, 144(4), 369-399.

Altuzarra, A., Gálvez-Gálvez, C., \& GonzálezFlores, A. (2019). Economic development and female labour force participation: 
The case of European Union countries. Sustainability (Switzerland), 11(7). https:// doi.org/10.3390/su11071962.

Apps, P., \& Rees, R. (2001). Fertility, female labor supply, and family policy. In IZA Discussion Papers (No. 409). https://doi. org/10.1111/j.1468-0475.2012.00568.x.

Assaad, R., Hendy, R., Lassasi, M., \& Yassin, S. (2018). Explaining the MENA Paradox: Rising Educational Attainment, Yet Stagnant Female Labor Force Participation. IZA Discussion Paper Series, (11385).

Bastian, B. L., Sidani, Y. M., \& El Amine, Y. (2018). Women entrepreneurship in the Middle East and North Africa: A review of knowledge areas and research gaps. Gender in Management, 33(1), 14-29. https://doi.org/10.1108/GM-07-2016-0141.

Demetriades, P., \& Law, S. H. (2006). Finance, institutions and economic development. International Journal of Finance and Economics, 11(3), 245-260. https://doi. org/10.1002/ijfe.296.

Demirgüç-Kunt, A., \& Maksimovic, V. (1998). Law, Finance, and Firm Growth. The Journal of Finance, LIII(6), 2107-2137.

Elson, D. (1999). Labor Markets as Gendered Institutions: Equality, E?ciency and Empowerment Issues. World Development, 27(3), 611-627. https:// doi.org/https://doi.org/10.1016/S0305750X(98)00147-8.

Engelhardt, H., \& Prskawetz, A. (2004). On the changing correlation between fertility and female employment over space and time. European Journal of Population, 20(1), 35-62. https://doi.org/10.1023/ B:EUJP.0000014543.95571.3b.

Gauthier, A. H., Emery, T., \& Bartova, A. (2016). The labour market intentions and behaviour of stay-at-home mothers in Western and Eastern Europe. Advances in Life Course Research, 30, 1-15. https:// doi.org/10.1016/j.alcr.2015.12.002.

Haas, B., Steiber, N., Hartel, M., \& Wallace, C. (2006). Household employment patterns in an enlarged European Union. Work, Employment and Society, 20(4), 751-771. https://doi. org/10.1177/0950017006069813.

Haghighat, E. (2002). Culture, development and female labor force participation: disaggregating different sectors. International Review of Sociology, 12(3), 343-362. https://doi.org/10.1080/0390670 022000041376.

Hayo, B., \& Caris, T. (2013). Female Labour Force Participation in the MENA Region: The Role of Identity. Review of Middle East Economics and Finance, 9(3), 271-292. https://doi.org/10.1515/rmeef-2013-0021.

Jensen, P. H. (2017). Cause and effects of female labour force participation in local welfare systems. European Societies, 19(2), 121-137. https://doi.org/10.1080/14 616696.2016.1268706.

Johansen, S. (1995). A Statistical Analysis of Cointegration forl (2)Variables. Econometric Theory, 11(1), 25-59. Retrieved from http:// www.jstor.org/stable/3532929.

King, R. G., \& Levine, R. (1993). Finance and Growth: Schumpeter Might Be Right. The Quarterly Journal of Economics, 108(3), 717-737. https://doi.org/10.2307/2118406. Kucera, D., \& Tejani, S. (2014). Feminization, defeminization, and structural change in manufacturing. World Development, 64, 569-582. https://doi.org/10.1016/j. worlddev.2014.06.033.

Loayza, N., \& Ranciere, R. (2005). Financial Development, Financial Fragility, and Growth. IMF Working Papers, 05(170), $1 . \quad$ https://doi. org/10.5089/9781451861891.001. 
Maddala, G. S., \& Wu, S. (1999). AComparative Study of Unit Root Tests with Panel Data and a New Simple Test. Oxford Bulletin of Economics and Statistics, 61(s1), 631652. https://doi.org/10.1111/1468-0084.61. s1.13.

Moghadam, V. M. (2005). Women's Economic Participation in the Middle East: What Difference Has The Neoliberal Policy Turn Made? Journal of Middle East Women's Studies, 1(1), 110-146. https://doi. org/10.2979/mew.2005.1.1.110

Pampel, F. C., \& Tanaka, K. (1986). Economic Development and Female Labor Force Participation: A Reconsideration. Social Forces, 64(3), 599. https://doi. org/10.2307/2578815.

Pesaran, M. H., Pesaran, M. H., Shin, Y., \& Smith, R. P. (1999). Pooled Mean Group Estimation of Dynamic Heterogeneous Panels. Journal of the American Statistical Association, 94(446), 621-634. https://doi. org/10.1080/01621459.1999.10474156.

Pesaran, M. H., \& Smith, R. (1995). Estimating long-run relationships from dynamic heterogeneous panels. In Journal of Econometrics (Vol. 68). https://doi. org/10.1016/0304-4076(94)01644-F.
Phillips, P. C. B., \& Hansen, B. E. (1990). Statistical Inference in Instrumental Variables Regression with I(1) Processes. The Review of Economic Studies, 57(1), 99. https://doi.org/10.2307/2297545.

Rendall, M. (2012). Rise of the Service Sector and Female Market Work: Europe vs US. Society for Economic Dynamics, pp. 1-30. https://doi.org/10.2139/ssrn.1635785.

Robinson, J. (2015). Female Labor Force Participation in the Middle East and North Africa Female Labor Force Participation in the Middle. Wharton Research Scholars, 28. Retrieved from http://repository.upenn. edu/wharton_research_scholars/28.

Schilirò, D. (2013). Diversification and development of the UAE' $s$ economy. Retrieved from https://mpra.ub.unimuenchen.de/84584/.

Welsh, D. H. B., Memili, E., Kaciak, E., \& Al Sadoon, A. (2014). Saudi women entrepreneurs: A growing economic segment. Journal of Business Research, 67(5), 758-762. https://doi.org/10.1017/ CBO9781107415324.004. 


\section{Appendices}

Table A1. Variables and Their Definitions

\begin{tabular}{lll}
\hline Variables & Variable definitions & Data source \\
\hline FLP & Female labor force participation rate & World Bank, 2014. \\
PLF & Total size of female labor force. & World Bank, 2014. \\
EDU & $\begin{array}{l}\text { Level of education measured by percentage of } \\
\text { educated people in the society. }\end{array}$ & World Bank, 2014. \\
LIVING & Cost of living index. & World Bank, 2014. \\
Capital & The level of capital stock of the economy. & World Bank, 2014. \\
Compensation \\
SGDP & The average wage compensation of the labor. & World Bank, 2014. \\
IGDP & Service share of total GDP & World Bank, 2014. \\
CREDIT & Industrial share of GDP & World Bank, 2014. \\
M2 & Domestic credit to private sector by banks & World Bank, 2014. \\
QOG & Broad money supply in the economy. & World Bank, 2014. \\
\hline
\end{tabular}

Table A2. List of Countries from The Data

\begin{tabular}{|l|l|l|}
\hline \multicolumn{2}{|c|}{ Countries Name } \\
\hline Algeria & Bahrain & Djibouti \\
\hline Egypt & Iran & Iraq \\
\hline Israel & Jordan & Kuwait \\
\hline Morocco & Oman & Qatar \\
\hline Saudi Arabia & Syria & Tunisia \\
\hline United Arab Emirates & Palestine & Yemen \\
\hline
\end{tabular}

